\title{
The Impact of Augmented Reality on E-learning Systems in Saudi Arabia Universities
}

\author{
Asma Alsayyar ${ }^{1} \&$ Riyad Almakki ${ }^{1}$ \\ ${ }^{1}$ Department of Information Systems, Al-Imam Muhammad Ibn Saud Islamic University, KSA \\ Correspondence: Asma Alsayyar, Department of Information Systems, Al-Imam Muhammad Ibn Saud Islamic \\ University, KSA.
}

Received: January 20, 2021

Accepted: March 8, $2021 \quad$ Online Published: March 16, 2021

doi:10.5539/cis.v14n2p50

URL: https://doi.org/10.5539/cis.v14n2p50

\begin{abstract}
The purpose of this paper was to investigate the impact of Augmented Reality on e-learning systems at colleges in Saudi Arabia. In this research, Augmented Reality could reenact real environment by computerized overlays that learners can interact with and without much of a stretch access. What is more, Augmented Reality helps consumers to explore alternative learning avenues around learning content. Setting that aside, there has not been sufficiently thorough research on the evaluation of Augmented Reality in the context of teaching. The primary objective of this research is to examine possible standard factors identified with the successful use of unparalleled scale. This prototype highlights the essential factors that affect the implementation of AR via the quantitative approach to Augmented Reality knowledge assortment and evaluation. The research finds the principal coefficients for the attainment of Augmented Reality: IT infrastructure, IT agility, interaction stability, self-learning ability, curriculum, student background, ease of use and Usefulness. The after-effects of this analysis includes useful debates to create up a perfect fate of Augmented Reality and help handle the enhancement of instruction and e-learning with competitive societies and frameworks in the Kingdom of Saudi Arabia as well as other countries.
\end{abstract}

Keywords: Electronic Learning (E-learning), Augmented Reality (AR), students, education, Saudi Arabia

\section{Introduction}

There are new suppositions, developments in the intelligent civilization, just as ideas that have evolved because of Internet exposure. New policies and applications are continually evolving amid these creative technologies and developments (Kaul, 2012). Various scholars argue that new learning is hugely affected by creativity. It is clear that creativity is being integrated into training and the effects of teaching and learning are positive. One of the most intuitive activities among people is the road towards learning. The outcome of the learning period is determined by the degree of collaboration between students and their teacher. In the learning cycle, e-learning and versatile learning have been implemented as of late. Similarly, previous reviews suggest that using technology to enhance preparation contributes to improved learning and training. Augmented Reality is a case of this (Christensen, 2002).

Computerized media is superimposed by innovation, as indicated by Fernandez (2017), so that legitimate users can use data through cell phones, PCs, as well as various gadgets. As of late, more attention has been given to Augmented Reality primarily, since Augmented Reality has not conceptualized the promotion of data access. According to Bimber and Raskar (2005), perspectives such as motion pictures, TV and PC games can be more than tools of amusement. They are used as entertainment devices in general, and this is an aspect that empowers them to be used when studying for friendly encounters. Edutainment is a term used when studying to refer to the use of diversion devices (Egenfeldt-Nielsen, 2005). E-learning is called the use of the Internet to enhance execution and data; it may also be known as separation learning. A fundamental reason for this research is to harness the ability of Augmented Reality to make learning enjoyable for students. This study investigates the influence of augmented reality on e-learning platforms at universities in Saudi Arabia. This study discusses the status of technology for Augmented Reality and e-learning. It ends with a review of the pros and constraints of the use of Augmented Reality in education. Incidentally, e-learning is more comprehensive and offers the ability for educational partners and organizers to provide learning resources from far-away electronic gadgets. Web-based learning materials can be delivered by electronic devices to understudies in higher learning 
establishments as per (Wang et al., 2005). Quick/fast web improvements have rendered fresh open doors for understudies. For students in higher learning foundations, conventional learning procedures represent a lot of difficulties, but several regions can be updated. Augmented Reality helps students to easily access data on virtual symbolism in the climate of reality. Therefore, it is becoming a trend to find learning institutions that use computer-aided educational models, combined with other multimedia-based features. In e-learning, for example, Chandrasekera and Yoon (2018) used an interactive program modelled on the lunar phase. Their results proved that by providing real-time information, multimedia courseware could significantly enhance learning.

\section{Literature Review}

Given the quickly expanding development of the mimicked based instructional methodologies, it is presently feasible for academicians to investigate more robust e-learning frameworks that encourage improved learning when contrasted with the ordinary models that are progressively becoming obsolete and insufficient (Dalim et al., 2017). The capacity to incorporate the advantages of useful innovations to convey answers for unhindered genuine climate will settle difficulties related with the ideas of certain subjects unnecessarily depending on abstracts. Other difficulties include a few investigations that need risky examinations, a few teaches that require extended periods to record perceptions, and the significant expense of undertaking analyses and impediments of reality (Yuen, Yaoyuneyong \& Johnson, 2013).

Examination on the conveyance of Augmented Reality in learning has picked up driving force in the ongoing past attributable to the way that the organization of different advancements in schooling has offered tremendous advantages and exceptional learning encounters. Olalde and Guesalaga (2013) saw that mimicked-based advances can help students acquire progressively enhanced and plentiful data to build a significant and complete image of learning ideas. Along these lines, it is turning into a pattern to discover learning foundations using PC helped instructional models, combined with different capacities dependent on media. For example, Chandrasekera and Yoon (2018) used intuitive programming displayed on the lunar stage in embraced e-learning. Their discoveries demonstrated that mixed media courseware could significantly improve learning by giving continuous information. Considering this and other ongoing model examinations, this part investigates and draws in with writing in regards to the organization of expanded reality in e-learning. Procedurally, it starts by looking at the e-learning ideas before exploring Augmented Reality and from that point, considers the components affecting increased validity in e-learning.

Web-based learning has more to do with the setting instead of the active use of innovation. For example, Elkins and Pinder (2015), see e-learning as the utilization of electronic advances to get to the instructive educational plan outside the ordinary homeroom. In a similar vein, Button, Harrington, and Belan (2014) present different ideas that allude to e-learning: separation instruction, web learning, and automated electronic learning among others. The current investigation, notwithstanding, embraced the Abdullah and Ward (2016) definition that depicts e-learning as casual and formalized learning accomplished by sending electronic (PC and organization innovations) assets, electronic and organization empowered exchange of information, and conveyance of learning materials.

Clark and Mayer (2016) partition e-learning into three significant perspectives, in particular, the circumstance of the course, the inclusion of the students and the utilization of an educator. These viewpoints incorporate simultaneous, accomplice, and offbeat learning. Appropriately, simultaneous learning happens when the students and educators are together simultaneously; however, not generally in a similar actual space (Abdullah \& Ward, 2016). Simultaneously, the educator and the students participate in e-learning with the utilization of electronic stages for coordinated learning, for example, GoToMeeting and Adobe associate (Garrison, 2011). Conversely, nonconcurrent learning includes self-guided discovering that happens freely of the association among students and educators. For associate learning, educators and students' finished undertakings like recordings, tasks, activities and readings (Ma et al., 2017). A foreordained target is set for the coursework, however inside the set periods, where understudies and teachers impart at their own time.

One of the advancements utilized in e-learning includes sound methods, including tuning in to materials using audio devices. Computerized sound consists of the portrayal of sound in both the prepared and carefully put away electronic structures. The web has various sound documents, recorded and sent for the reasons of learning. While radio has been used for quite a while in the regular study hall (Button, Harrington and Belan, 2014), in the ongoing past, movement in innovation has seen the joining of radio on the web by means of streaming. Moreover, digital recordings and webcasts that can be downloaded by the students and educators have quickly become a typical element on the web. Video-empowered advances are additionally apparent in the study hall today. They include electronic media that record, duplicate and broadcast vivified visual pictures. The 
method is used by understudies who need graphic images, including seeing the materials rather than just perusing (Urh, Vukovic \& Jereb, 2015). These days, educators approach massive video cuts employing the web rather than the conventional Video Home System (VHS ) tapes and Digital Video Disc (DVD). In the present day, online destinations, for example, YouTube are conveyed by student and educator (Abdullah \& Ward, 2016). Additionally, instructors are using Adobe interface, webcams, and Skype applications to communicate effectively and frequently with the learners. The utilization of video-empowered learning advances has been esteemed to expand the maintenance of substance and help accomplish better execution in class. Efficient video advancement approaches are creating video models that are emphatically affecting learning measures (Bernard et al., 2014). Other than sound and video advancements, students approach cell phones, tablets, and PCs, which are broadly used in the homeroom.

SmartBuilder, an e-picking up writing instrument, is likewise used in e-learning for making course materials (Al-Samarraie et al., 2018). To manufacture e-adapting course materials, academicians do not need to code the program. They can utilize SmartBuilder application. Another discovery in e-learning involves human-made reasoning, including machines that structure a differentiation with the characteristic human knowledge (Huda et al., 2018). Human-made brainpower Artificial Intelligence (AI) is changing the whole experience of e-learning ascribed to its advantages. Human-made intelligence can help with featuring disciplines that need to upgrade as help students to improve in a portion of their frail territories. Progressed human-made brainpower models are taking care of various issues for the clients in a broadway when contrasted with the involved actual study hall approach.

The computer-generated reality or Virtual reality (VR) is another innovation that has been utilized in e-getting the hang of, including using headsets and complex-extended conditions, just as the actual climate or prop to offer reasonable sensations, pictures, recordings and sounds that improve the clients' essence inside a virtual or symbolism climate (Merchant et al., 2014). The remarkable utilitarian capacity and relevance of computer-generated reality have made it normal in e-learning, with possible applications in preparing material science and clinical preparing being the most encouraging. The advantages of computer-generated reality in e-learning has been investigated in different examinations. Dalim et al. (2017) saw that VR permits understudies to send data and information over the globe in a brief timeframe, as they use drawing in and invigorating instructive functionalities. Much the same as different innovations, VR has been found to intensify students' inspiration, since they do not stay with various pages of exhausting writings or delineations that they need to peruse. VR offers the opportunity to experience a genuine encounter, in actuality, on the planet outside the homeroom. As per Bacos and Carroll (2018), VR holds a substantial potential past the gaming business in regions, for example, VR films, music, game, schooling and preparing.

Another significant developing innovation includes the Augmented Reality (AR) that superimposes PC created content on the client's perspective on the genuine world and offers a composite view. It incorporates real tangible information, for example, sound, designs, pictures and recordings. Kipper and Rampolla (2013) set that in e-learning, AR can make the whole learning measure all the more intriguing just as simpler for the students to get a handle on. For instance, an online educator can offer a virtual visit through Mars without visiting the spot nor requesting that the understudies leave their home in a cosmic subject (Pérez-López \& Contero, 2013). The innovation is beneficial, and numerous specialists have anticipated that enlarged reality market will come to the $\$ 200$ billion marks regularly 2024, showing gigantic probability later on. Like computer-generated simulation, $\mathrm{AR}$ assembles a learning experience utilizing 3D displaying programming and can be gotten to using $\mathrm{AR}$ headsets (Bistaman, Idrus \& Rashid, 2018).

\section{Methodology}

The objective populace of the investigation were college understudies in Saudi Arabia after characterizing objective. This proposition received a Non-Probability purposive examining strategy. Hair et al. (2003) characterized non-Probability purposive testing as a cycle that includes choosing individuals from an example with information about a specific issue, the capacity to give the vital data, and the availability to be engaged with the investigation. Approximately 288 understudies participated in the study. However, 109 of members have left the survey page without finishing the remainder of inquiries. Therefore, the quantity of complete substantial polls is 179.The motivation behind this examination is the comprehension of applying Augmented Reality and their effects in Saudi Arabia colleges, as well as the key factors that assume a necessary function in the execution of the Augmented Reality in Saudi Arabia colleges.

This examination utilized both primary and secondary data. It gave essential data to accomplish the proposition. Likewise, the necessary and optional information supplement one another. In this proposal, vital information was 
gathered using circulated overview, in a type of an electronic survey. Electronic polls estimate that a scientist can send them to an enormous number of people inside a limited ability to focus on investing cash and energy in talking each respondent on an individual premise (Patel, 2009). The number of inhabitants in the investigation will be college understudies in Saudi Arabia.

\section{Results and Discussion}

By testing the hypotheses, the researcher will be able to examine the level of influence of each key factor and the overall influence on the implementation of Augmented Reality in Saudi Arabia universities, regression analysis was conducted and the results are presented in Table 1. In addition, Table 1 contains a set of values that explain the relationship between dependent variable and independent variables; the main values are (R2, F-statistics, T-test, beta -value and P-value).

$\mathrm{R}$ square showed rate variety in the depended variable that can be anticipated by the autonomous factors, is additionally called the coefficient of assurance-F-measurements, which used to test the general criticalness of the relapse model. The T-test was valuable for making deductions about the relapse coefficients. Beta worth analyzed the quality of the impact of every free factor on subordinate factors. It was determined that the higher estimation of the beta coefficient, the more grounded impact. Besides, the P-esteem clarified the criticalness of the model, if p-esteem under 0.05, the model is measurably huge. If it is higher than 0.05 , the model is not measurably huge (saunders et al., 2012). The outcomes in Table 1, showed that the general essentialness of the exploration model was spoken to in Table 1 , where $\mathrm{F}=105.096$ and $\mathrm{P}=0.00(\mathrm{P}<0.01)$. The estimation of F-measurements was measurably critical at the (0.01) level, implying that, the various relapse model could analyze and decide the key factors that effect on the execution of Augmented Reality in Saudi Arabia colleges. Notwithstanding that, the outcomes uncovered the coefficient of assurance (R2) is coming to (0.832), which demonstrated that the critical components remembered for the model was proficient at appraising the progressions on the execution of viable AR in Saudi colleges. The outcomes showed the essential elements clarified about $83.0 \%$ of the varieties in the usage of AR in Saudi colleges.

In light of the consequence of numerous relapse examination that was introduced in Table 1, which tried impact of IT infrastructure on the fruitful usage of Augmented Reality ( $\mathrm{T}=7.614, \mathrm{P}=0.00$ that is under 0.01$)$. In this manner, the speculation H1a (there is a measurably critical impact of IT infrastructure on the fruitful execution of Augmented Reality in Saudi colleges) was upheld. Accordingly, the speculation H1b (there is a measurably huge impact of IT agility of mastery on the effective execution of Augmented Reality in Saudi colleges) was upheld. In light of the consequence of different relapse investigation that is introduced in Table 1, which tried impact of interaction stability on the fruitful execution of Augmented Reality ( $\mathrm{T}=3.709, \mathrm{P}=0.00$ that is under 0.01). In this manner, the speculation H1c (there is a measurably huge impact of interaction stability on the practical usage of Augmented Reality in Saudi colleges) was upheld. About the test which tried the effect of the ability of Self-learning on the fruitful execution of Augmented Reality ( $T=3.934, \mathrm{P}=0.00$ that is under 0.01 ). In this manner, the speculation H1d (There is a measurably massive impact of the ability of Self-learning on the practical usage of Augmented Reality in Saudi colleges) was upheld.

Again, the consequence of different relapse investigation that was introduced in Table 1, which tried impact of Curricula on the fruitful execution of Augmented Reality $(\mathrm{T}=1.008, \mathrm{P}=0.32(\mathrm{P}>0.05)$ that is more noteworthy than 0.05). Consequently, the theory H1e (there is a factually huge impact of Curricula on the fruitful execution of Augmented Reality in Saudi colleges) was dismissed. The trial which tried result of Students' background on the fruitful execution of Augmented Reality was found to be $\mathrm{T}=2.126, \mathrm{P} \leq 0.05$. Accordingly, the speculation H1f (there is a measurably huge impact of Students' background on the fruitful execution of Augmented Reality in Saudi colleges) was upheld.

Based on the impact Easy to use on the effective execution of Augmented Reality ( $\mathrm{T}=-0.565, \mathrm{P}=0.57(\mathrm{P}>0.05)$ that is more prominent than 0.05). Like this, the speculation H1g (there is a factually huge impact of Easy to use on the effective execution of Augmented Reality in Saudi colleges) was dismissed. At last, based on the test impact of Usefulness on the fruitful usage of Augmented Reality was ( $\mathrm{T}=3.65^{* *}, \mathrm{P}=0.00$ that is under 0.01 ). Accordingly, the speculation H1h (there is a measurably critical impact of Usefulness on the effective execution of Augmented Reality in Saudi colleges) was upheld. 
Table 1. Illustrates multiple regression analysis regarding the influence of the key factors on the implementation of augumented reality in Saudi Arabia Universities

\begin{tabular}{|c|c|c|c|c|c|c|}
\hline Model & Coefficients & Beta & T-test & P-value & $\mathrm{F}$ & Sig. \\
\hline Constant & 0.109 & & 0.739 & 0.46 & \multirow{9}{*}{$105.096^{* *}$} & \multirow{9}{*}{0.00} \\
\hline IT technology / infrastructure & 0.239 & 0.310 & $7.614 * *$ & 0.00 & & \\
\hline Influence of agility & 0.067 & 0.085 & $1.994^{*}$ & 0.048 & & \\
\hline Interaction's stability & 0.176 & 0.195 & $3.709^{* *}$ & 0.00 & & \\
\hline $\begin{array}{l}\text { The capability of } \\
\text { Self-learning }\end{array}$ & 0.146 & 0.180 & $3.934 * *$ & 0.00 & & \\
\hline Curricula & 0.058 & 0.067 & 1.0008 & 0.32 & & \\
\hline Students' background & 0.108 & 0.120 & $2.126^{*}$ & 0.04 & & \\
\hline Easy to use & -0.019 & -0.026 & -0.565 & 0.57 & & \\
\hline Usefulness & 0.197 & 0.203 & $3.650^{* *}$ & 0.00 & & \\
\hline \multicolumn{2}{|l|}{$\mathrm{R}=0.912$} & \multicolumn{5}{|c|}{ Adj. $R^{2}=0.824$} \\
\hline
\end{tabular}

**indicated that F-statistics, and T-test is significant at the (0.01) level

*Indicated that T-test statistics is significant at the $(0.05)$ level.

\section{Conclusion and Future Recommendations}

The results outline that an aggregate of eight examination theory was tried to look at if the free factors altogether clarified the needy variable. The outcome uncovered that the free factor, IT infrastructure, is the main key element that impacts decidedly on the execution of AR in Saudi colleges, while the subsequent key factor that affect AR usage was the interaction stability. At the same time, the ability of self-learning was the third key factor that likewise impacts emphatically and altogether on the execution of AR in Saudi colleges. Usefulness was the fourth affecting element, and student background has impacted decidedly and entirely. IT agility impacts AR usage. The two factors that seemed to have no critical impact were curriculum and ease of use. The examination gave a few occasions to additional assessment, given that the topic centered around a moderately new space of the utilization of AR in instruction. As innovation is opening up for use in learning, the requirement for such exploration increments. Exploration here will support the selection of increased reality innovation-based training and aid the improvement of the innovation.

There are different recommendations in which future examination is required. The research could be reproduced in other Arabic nations to see whether Augmented Reality on e-learning frameworks in Saudi Arabia colleges would be figured it out. Its replication could likewise help extend the discoveries or discredit them. Moreover, future exploration may duplicate these elements in other nations' setting to guarantee the legitimacy of the proposed calculated model. Additionally, an alternate information investigation technique could likewise be adjusted to test the legitimacy of the ebb and flow research. The attention on the various territories of exploration would assume a focal part in guaranteeing a more extensive viewpoint of the examination that has been distinguished. Future exploration can complete a longitudinal report rather than a cross-sectional examination to researching how enlarged reality impacts e-learning frameworks in Saudi Arabia colleges. Such an examination is a commendable heading and requires future exploration endeavors. It would give another point of view on the exploration subject and accordingly giving extra information on the zone of study.

\section{References}

Abdullah, F., \& Ward, R. (2016). Developing a General Extended Technology Acceptance Model for E-Learning (GETAMEL) by analyzing commonly used external factors. Computers in Human Behavior, 56, 238-256. https://doi.org/10.1016/j.chb.2015.11.036

Abou-Elhamd, K. A., Al-Sultan, A. I., \& Rashad, U. M. (2010). Simulation in ENT medical education. The Journal of Laryngology \& Otology, 124(3), 237-241. https://doi.org/10.1017/S0022215109991885 
Akçayır, M., \& Akçayır, G. (2017). Advantages and challenges associated with augmented reality for education: A systematic review of the literature. Educational Research Review, 20, 1-11. https://doi.org/10.1016/j.edurev.2016.11.002

Al Kilani, M., \& Kobziev, V. (2016). An Overview of Research Methodology in Information System (IS). Open Access Library Journal, 3(11), 1. https://doi.org/10.4236/oalib.1103126

Alahmari, M. S. (2020). Developing, Understanding and Evaluating Augmented Reality Framework for Universities in Saudi Arabia.

Alcaniz, M., Perez-Lopez, D. C., Contero, M., \& Ortega, M. (2010). Augmented reality technology for education. INTECH Open Access Publisher. https://doi.org/10.5772/9228

Alenezi, A. (2015). Influences of the Mandated Presence of ICT in Saudi Arabia Secondary Schools. International Journal of Information and Education Technology, 5(8), 638-644. https://doi.org/10.7763/IJIET.2015.V5.583

Alfahad, F. N. (2012). Effectiveness of Using Information Technology in Higher Education in Saudi Arabia. Procedia - Social and Behavioral Sciences, 46, 1268-1278. https://doi.org/10.1016/j.sbspro.2012.05.287

AlGhamdi, R., Nguyen, A., Nguyen, J., \& Drew, S. (2011). Factors influencing Saudi customers' decisions to purchase from online retailers in Saudi Arabia: a quantitative analysis. In IADIS International Conference e-commerce 2011 (pp. 153-161).

Alhalabi, W. (2016). Advancing Attention Control Using VR-Induced Artificial Synesthesia.

Al-Juraishi, M. (2020). After the decision to suspend the study, did "distance education" prove its worth or not? Educational Field Newspaper. Retrieved from https: //almaydanedu.net/705218/

Al-Samarraie, H., Teng, B. K., Alzahrani, A. I., \& Alalwan, N. (2018). E-learning continuance satisfaction in higher education: a unified perspective from instructors and students. Studies in Higher Education, 43(11), 2003-2019. https://doi.org/10.1080/03075079.2017.1298088

Alzahrani, N. M. (2020). Augmented Reality: A Systematic Review of Its Benefits and Challenges in E-learning Contexts. Applied Sciences. https://doi.org/10.3390/app10165660

Alzain, H. A. (2018). A proposed educational program to develop students'skills in designing Augmented Reality technology among students of Princess Nourah bint Abdulrahman University and its impact on increasing their learning motivation (Vol. 14). Diyala University.

Anshari, M., Alas, Y., \& Guan, L. S. (2016). Developing online learning resources: Big data, social networks, and cloud computing to support pervasive knowledge. Education and Information Technologies, 21(6), 1663-1677. https://doi.org/10.1007/s10639-015-9407-3

Arab Universities on the Road to Virtual Reality. (2016, November 01). Retrieved from https://www.al-fanarmedia.org/ar/2016/10/21716/

Arvanitis, T. N., Petrou, A., Knight, J. F., Savas, S., Sotiriou, S., Gargalakos, M., \& Gialouri, E. (2009). Human factors and qualitative pedagogical evaluation of a mobile augmented reality system for science education used by learners with physical disabilities. Personal and ubiquitous computing, 13(3), 243-250. https://doi.org/10.1007/s00779-007-0187-7

Atmowardoyo, H. (2018). Research Methods in TEFL Studies: Descriptive Research, Case Study, Error Analysis, and R \& D. Journal of Language Teaching and Research, 9(1), 197-204. https://doi.org/10.17507/jltr.0901.25

Azuma, R. T. (1997). A survey of augmented reality. Presence: Teleoperators \& Virtual Environments, 6(4), 355-385. https://doi.org/10.1162/pres.1997.6.4.355

Babbie, E. (2010). The Practice of Social Research (12nd ed.). Belmont, CA: Wadsworth.

Bacca, J., Baldiris, S., \& Ramon Fabregat, K. (2018). Insights into the factors influencing student motivation in augmented reality learning experiences in vocational education and training. Frontiers in psychology, 9. https://doi.org/10.3389/fpsyg.2018.01486

Bacos, C., \& Carroll, M. (2018, October). Kinematics for E-Learning: Examining Movement and Social Interactions in Virtual Reality. In E-Learn: World Conference on E-Learning in Corporate, Government, Healthcare, and Higher Education (pp. 559-563). Association for the Advancement of Computing in Education (AACE). 
Bai, Z., Blackwell, A. F., \& Coulouris, G. (2013, October). Through the looking glass: Pretend play for children with autism. In Mixed and augmented reality (ISMAR), 2013 IEEE International Symposium on (pp. 49-58). IEEE. https://doi.org/10.1109/ISMAR.2013.6671763

Ball, S., Panning, M., Miller, J., Schoening, A., Koziol, D., Selig, C., ... Koster, E. (2017, June). The Use of Augmented Reality to Increase Efficiency in Preparing Undergraduate Nursing Students for New Clinical Settings. In EdMedia: World Conference on Educational Media and Technology (pp. 1199-1204). Association for the Advancement of Computing in Education (AACE).

Bendicho, P. F., Mora, C. E., Añorbe-Díaz, B., \& Rivero-Rodríguez, P. (2016). Effect on academic procrastination after introducing augmented reality. EURASIA Journal of Mathematics, Science and Technology Education, 13(2), 319-330. https://doi.org/10.12973/eurasia.2017.00618a

Bernard, R. M., Borokhovski, E., Schmid, R. F., Tamim, R. M., \& Abrami, P. C. (2014). A meta-analysis of blended learning and technology use in higher education: From the general to the applied. Journal of Computing in Higher Education, 26(1), 87-122. https://doi.org/10.1007/s12528-013-9077-3

Billinghurst, M. (2013, December). Hands and speech in space: multimodal interaction with augmented reality interfaces. In Proceedings of the 15th ACM on International conference on multimodal interaction (pp. 379-380). ACM. https://doi.org/10.1145/2522848.2532202

Bimber, O., \& Raskar, R. (2005). Spatial Augmented Reality: Merging Real and Virtual Worlds. CRC Press. https://doi.org/10.1201/b10624

Bistaman, I. N. M., Idrus, S. Z. S., \& Rashid, S. A. (2018, June). The Use of Augmented Reality Technology for Primary School Education in Perlis, Malaysia. In Journal of Physics: Conference Series (Vol. 1019, No. 1, p. 012064). IOP Publishing. https://doi.org/10.1088/1742-6596/1019/1/012064

Bower, M., Howe, C., McCredie, N., Robinson, A., \& Grover, D. (2014). Augmented Reality in education - cases, places and potentials. Educational Media International, 51(1), 1-15. https://doi.org/10.1080/09523987.2014.889400

Button, D., Harrington, A., \& Belan, I. (2014). E-learning \& information communication technology (ICT) in nursing education: A review of the literature. Nurse education today, 34(10), 1311-1323. https://doi.org/10.1016/j.nedt.2013.05.002

Carbonell Carrera, C., \& Bermejo Asensio, L. A. (2017). Landscape interpretation with augmented reality and maps to improve spatial orientation skill. Journal of Geography in Higher Education, 41(1), 119-133. https://doi.org/10.1080/03098265.2016.1260530

Cascales, A., Laguna, I., Pérez-López, D., Perona, P., \& Contero, M. (2013, July). An experience on natural sciences augmented reality contents for preschoolers. In International Conference on Virtual, Augmented and Mixed Reality (pp. 103-112). Springer, Berlin, Heidelberg.

https://doi.org/10.1007/978-3-642-39420-1_12

Chandrasekera, T., \& Yoon, S. Y. (2018). Augmented Reality, Virtual Reality and Their Effect on Learning Style in the Creative Design Process. Design and Technology Education, 23(1), n1. https://doi.org/10.4018/IJVAR.2018010101

Chang, S. C., \& Hwang, G. J. (2018). Impacts of an augmented reality-based flipped learning guiding approach on students' scientific project performance and perceptions. Computers \& Education. https://doi.org/10.1016/j.compedu.2018.06.007

Chen, C. M., \& Tsai, Y. N. (2012). Interactive augmented reality system for enhancing library instruction in elementary schools. Computers \& Education, 59(2), 638-652. https://doi.org/10.1016/j.compedu.2012.03.001

Chen, P., Liu, X., Cheng, W., \& Huang, R. (2017). A review of using Augmented Reality in Education from 2011 to 2016. In Innovations in Smart Learning (pp. 13-18). Springer, Singapore. https://doi.org/10.1007/978-981-10-2419-1_2

Cheng, K. H. (2017). Reading an augmented reality book: An exploration of learners' cognitive load, motivation, and attitudes. Australasian Journal of Educational Technology, 33(4). https://doi.org/10.14742/ajet.2820

Cheng, K. H., \& Tsai, C. C. (2013). Affordances of augmented reality in science learning: Suggestions for future research. Journal of Science Education and Technology, 22(4), 449-462. https://doi.org/10.1007/s10956-012-9405-9 
Christensen, R. (2002). Effects of Technology Integration Education on the Attitudes of Teachers and Students. Journal of Research on Technology in Education, 34(4), 411-433. https://doi.org/10.1080/15391523.2002.10782359

Churchill, G. (1991). Marketing Research: Methodological Framework (5th ed.). Fort Worth: The Dryden Press.

Clark, R. C., \& Mayer, R. E. (2016). E-learning and the science of instruction: Proven guidelines for consumers and designers of multimedia learning. John Wiley \& Sons. https://doi.org/10.1002/9781119239086

Collis, J., \& Hussey, R. (2013). Business research: A practical guide for undergraduate and postgraduate students. Macmillan International Higher Education.

Creswell, J. (2009). Research design (3rd ed.). Thousand Oaks, Calif.: sage publications.

Dalim, C. S. C., Kolivand, H., Kadhim, H., Sunar, M. S., \& Billinghurst, M. (2017). Factors influencing the acceptance of augmented reality in education: A review of the literature. Journal of computer science, 13(11), 581-589. https://doi.org/10.3844/jcssp.2017.581.589

Daniel, E. (2016). The Usefulness of Qualitative and Quantitative Approaches and Methods in Researching Problem-Solving Ability in Science Education Curriculum. Journal of Education and Practice, 7(15), 91-100.

Derue, D., Ashford, S. J., \& Myers, C. G. (2012). Learning agility: In Search of Conceptual Clarity and Theoretical Grounding. Industrial and Organizational Psychology, 5, 258-279. https://doi.org/10.1111/j.1754-9434.2012.01444.x

Diaz, V. M. (2017). The relationships between augmented reality and inclusive education in higher education.

Distance education application proved effective during the crisis in Corona. (2020). Alriyadh202. Retrieved from http://www.alriyadh.com

Dunleavy, M., Dede, C. \& Mitchell, R. (2009). Affordances and Limitations of Immersive Participatory Augmented Reality Simulations for Teaching and Learning.J Sci Educ Technol, 18, 7-22. https://doi.org/10.1007/s10956-008-9119-1

Egenfeldt-Nielsen, S., (2005). Beyond edutainment: Exploring the educational potential of computer games. Copenhagen: IT University of Copenhagen, Department of Innovation.

Elia, V., Gnoni, M. G., \& Lanzilotto, A. (2016). Evaluating the application of augmented reality devices in manufacturing from a process point of view: An AHP based model. Expert Systems with Applications, 63, 187-197. https://doi.org/10.1016/j.eswa.2016.07.006

Elkins, D., \& Pinder, D. (2015). E-learning fundamentals: A practical guide. American Society for Training and Development.

Ferdig, R. E. (2006). Assessing technologies for teaching and learning: understanding the importance of technological pedagogical content knowledge. British Journal of Educational Technology, 37, 749-760. https://doi.org/10.1111/j.1467-8535.2006.00559.x

Fernandez, M. (2017). Augmented-Virtual Reality: How to improve education systems. Higher Learning Research Communications, 7(1), 1. https://doi.org/10.18870/hlrc.v7i1.373

Ferrer-Torregrosa, J., Jiménez-Rodríguez, M. Á., Torralba-Estelles, J., Garzón-Farinós, F., Pérez-Bermejo, M., \& Fernández-Ehrling, N. (2016). Distance learning ects and flipped classroom in the anatomy learning: comparative study of the use of augmented reality, video and notes. BMC medical education, 16(1), 230. https://doi.org/10.1186/s12909-016-0757-3

Garrison, D. R. (2011). E-learning in the 21st century: A framework for research and practice. Routledge. https://doi.org/10.4324/9780203838761

Ghavifekr, S., Kunjappan, T., Ramasamy, L., \& Anthony, A. (2016). Teaching and Learning with ICT Tools: Issues and Challenges from Teachers' Perceptions. Malaysian Online Journal of Educational Technology, 4(2), 38-57.

Green, S. B., \& Salkind, N. J. (2016). Using SPSS for Windows and Macintosh, books a la carte. Pearson.

Gupta, N., \& Bharadwaj, S. (2013). Agility in business school education through richness and reach: a conceptual model. Education + Training, 55, 370-384. https://doi.org/10.1108/00400911311326018

Gutierrez, J. M., Guinters, E., \& Lopez, D. P. (2012). Improving Strategy of Self-Learning in Engineering: 
Laboratories with Augmented Reality. Procedia - Social and Behavioral Sciences, 51, 832-839. https://doi.org/10.1016/j.sbspro.2012.08.249

Hair, J. B., \& Money, B. A. H., \& Samouel, P. (2003). Essentials of Business Research Methods. John Wiley and Sons, Inc.

Hamidi, F., Meshkat, M., Rezaee, M., \& Jafari, M. (2011). Information Technology in Education. Procedia CS., 3. 369-373. https://doi.org/10.1016/j.procs.2010.12.062

Hantono, B. S., Nugroho L. E., \& Santosa, P. I. (2018). Meta-Review of Augmented Reality in Education, 10th International Conference on Information Technology and Electrical Engineering (ICITEE). https://doi.org/10.1109/ICITEED.2018.8534888

Harders, M., Bianchi, G., Knoerlein, B., \& Szekely, G. (2009). Calibration, Registration, and Synchronization for High Precision Augmented Reality Haptics. IEEE Transactions on Visualization and Computer Graphics, 15(1), 138-149. https://doi.org/10.1109/TVCG.2008.63

Harley, J. M., Poitras, E. G., Jarrell, A., Duffy, M. C., \& Lajoie, S. P. (2016). Comparing virtual and location-based augmented reality mobile learning: emotions and learning outcomes. Educational Technology Research and Development, 64(3), 359-388. https://doi.org/10.1007/s11423-015-9420-7

Hassan, A. (2017). The concept of augmented reality. Technologies and Information Electronic. Retrieved from https://www.babonej.com/augmented-reality-1085.html

Hinton, P., Brownlow, C., McMurray, I., \& Cozens, B. (2004). SPSS explained. East Sussex. England: Routledge Inc. https://doi.org/10.4324/9780203642597

Hoffman, D. M. (2015). U.S. Patent Application No. 14/704,777.

Horton, W. (2011). E-learning by design. John Wiley \& Sons. https://doi.org/10.1002/9781118256039

Hsu, T. C. (2017). Learning English with augmented reality: Do learning styles matter? Computers \& Education, 106, 137-149. https://doi.org/10.1016/j.compedu.2016.12.007

Huda, M., Maseleno, A., Atmotiyoso, P., Siregar, M., Ahmad, R., Jasmi, K., \& Muhamad, N. (2018). Big data emerging technology: insights into innovative environment for online learning resources. International Journal of Emerging Technologies in Learning (iJET), 13(1), 23-36. https://doi.org/10.3991/ijet.v13i01.6990

Hussain, I., \& Muhammad, S. (2008). Role of information technologies in teaching learning process: Perception of the faculty. The Turkish Online Journal of Distance Education, 9.

Juan, M., Alexandrescu, L., Folguera, F., \& García García, I. (2016). A Mobile Augmented Reality system for the learning of dental morphology. Digital Education Review, 30, 234-247.

Kaufmann, H., \& Meyer, B. (2008). Simulating educational physical experiments in augmented reality (pp. 3). ACM. https://doi.org/10.1145/1507713.1507717

Kaul, V. (2012). The Changing World of Media \& Communication. Journal of Mass Communication and Journalism, 02(06). https://doi.org/10.4172/2165-7912.1000116

Kim, K., Hwang, J., Zo, H., \& Lee, H. (2016). Understanding users' continuance intention toward smartphone augmented reality applications.

Kipper, G., \& Rampolla, J. (2013). Augmented Reality, An Emerging Technology Guide to AR.

Kirner, T. G., Reis, F. M. V., \& Kirner, C. (2012, June). Development of an interactive book with augmented reality for teaching and learning geometric shapes. In 7th Iberian Conference on Information Systems and Technologies (CISTI 2012) (pp. 1-6). IEEE.

Kothari, C., \& Garg, G. (2016). Research Methodology (1st ed.). New Delhi :New Age International (p) Limited.

Krevelen, R. V. (2007). Augmented Reality: technologies, applications, and limitations.

Küçük, S., Kapakin, S., \& Göktaş, Y. (2016). Learning anatomy via mobile augmented reality: effects on achievement and cognitive load. Anatomical sciences education, 9(5), 411-421. https://doi.org/10.1002/ase.1603

Kysela, J., \& Štorková, P. (2015). Using augmented reality as a medium for teaching history and tourism. Procedia-Social and behavioral sciences, 174, 926-931.

https://doi.org/10.1016/j.sbspro.2015.01.713 
Lai, A. F., Chen, C. H., \& Lee, G. Y. (2018). An augmented reality-based learning approach to enhancing students' science reading performances from the perspective of the cognitive load theory. British Journal of Educational Technology. https://doi.org/10.1111/bjet.12716

Latif, F. (2012). CARE: Creating Augmented Reality in Education. In T. Amiel \& B. Wilson (Eds.), Proceedings of EdMedia 2012--World Conference on Educational Media and Technology.

Learntech .uwe.ac.uk. (2016). Data Analysis - Pearson's Correlation Coefficient. [online] Retrieved from http://learntech.uwe.ac.uk/da/Default.aspx?pageid=1442 [August 08, 2020].

Lee, G. A., \& Kim, G. J. (2009). Immersive authoring of Tangible Augmented Reality content: A user study. Journal of Visual Languages \& Computing, 20(2). https://doi.org/10.1016/j.jvlc.2008.07.001

Leedy, P. D., \& Ormrod, Jeanne E. (2001). Practical Research: Planning and Design (7th ed.). Upper Saddle River, NJ: Merrill Prentice Hall.

Liarokapis, F. (2007). An augmented reality interface for visualizing and interacting with virtual content. Virtual Reality, 11, 23-43. https://doi.org/10.1007/s10055-006-0055-1

Liarokapis, F., \& Anderson, E. F. (2010). Using augmented reality as a medium to assist teaching in higher education.

Ma, C. W., Chan, L. K., Lam, I. H. Y., \& Chan, Y. S. (2017). Use of Augmented Reality to Optimize the Effectiveness of Biomedical Education. In The 9th Asian Medical Education Association Symposium cum Frontiers in Medical and Health Sciences Education. Li Ka Shing Faculty of Medicine, The University of Hong Kong.

MacDonald, S., \& Headlam, N. (2014). Research Methods Handbook, Introductory Guide to Research Methods for Social Research. Manchester: Centre for Local Economic Strategies.

Malhotra, N. K. (2015). Essentials of marketing research: A hands-on orientation. Essex: Pearson.

Malik, S., McDonald, C., Roth, G. (2002). Hand tracking for interactive pattern-based augmented reality. Proceedings: International Symposium on Mixed and Augmented Reality, 117-126.

Mandela, N. (2014). Education is the most powerful weapon which you can use to change the world. Computer, 8 , $45 \mathrm{pm}$.

Martin-Gonzalez, A., Chi-Poot, A., \& Uc-Cetina, V. (2016). Usability evaluation of an augmented reality system for teaching Euclidean vectors. Innovations in education and teaching International, 53(6), 627-636. https://doi.org/10.1080/14703297.2015.1108856

Maseleno, A., Huda, M., Teh, K. S. M., Don, A. G., Basiron, B., Jasmi, K. A., ... \& Ahmad, R. (2018). Understanding Modern Learning Environment (MLE) in Big Data Era. International Journal of Emerging Technologies in Learning (iJET), 13(05), 71-85. https://doi.org/10.3991/ijet.v13i05.8042

Masoni, R., Ferrise, F., Bordegoni, M., Gattullo, M., Uva, A. E., Fiorentino, M., ... Donato, M. D. (2017). Supporting remote maintenance in industry 4.0 through augmented reality. Procedia Manufacturing, 11, 1296-1302. https://doi.org/10.1016/j.promfg.2017.07.257

McLean, G., \& Wilson, A. (2019). Shopping in the digital world: Examining customer engagement through augmented reality mobile applications. Computers in Human Behavior, 101, 210-224. https://doi.org/10.1016/j.chb.2019.07.002

Merchant, Z., Goetz, E. T., Cifuentes, L., Keeney-Kennicutt, W., \& Davis, T. J. (2014). Effectiveness of virtual reality-based instruction on students' learning outcomes in K-12 and higher education: A meta-analysis. Computers \& Education, 70, 29-40. https://doi.org/10.1016/j.compedu.2013.07.033

Miller, S. A. (2015). U.S. Patent No. 9,215,293. Washington, DC: U.S. Patent and Trademark Office.

Ministry of Education. (2019). Saudi Vision 2030. Retrieved from https://www.moe.gov.sa/en/Pages/vision2030.aspx

Misra, B. M. S., Torre, A. M. A. R. C., Falcão, J. G. R. M. I., Apduhan, D. T. B. O., \& Gervasi, O. (2019). Computational Science and Its Applications-ICCSA 2019. Springer International Publishing.

Mitchell, R. (2011). Alien Contact!: Exploring teacher implementation of an augmented reality curricular unit. Journal of Computers in Mathematics and Science Teaching, 30(3), 271-302.

Montoya, M. H., Díaz, C. A., \& Moreno, G. A. (2016). Evaluating the effect on user perception and performance 
of static and dynamic contents deployed in augmented reality-based learning application. Eurasia Journal of Mathematics, Science and Technology Education, 13(2), 301-317. https://doi.org/10.12973/eurasia.2017.00617a

National Transformation Program 2020. Kingdom of Saudi Arabia. Retrieved from http://argaamplus.s3.amazonaws.com/417177d0-c22b-432b-9602-417ec7d45050.pdf

Nicaean, D., Alia, M. B., Abdul Halim, N. D., \& Abdul Rahman, M. H. (2013, December 14). Mobile Augmented Reality: The Potential for Education Procedia-Social and Behavioral Sciences, 103, 657-664. https://doi.org/10.1016/j.sbspro.2013.10.385

Nicholls, A. (2018). Managing educational innovations. Routledge. https://doi.org/10.4324/9781351040860

Nincarean, D., Alia, M. B., Halim, N. D. A., \& Rahman, M. H. A. (2013). Mobile augmented reality: The potential for education. Procedia-Social and Behavioral Sciences, 103, 657-664. https://doi.org/10.1016/j.sbspro.2013.10.385

Olalde, K., \& Guesalaga, I. (2013). The New Dimension in a Calendar: The Use of Different Senses and Augmented Reality Apps. Procedia Computer Science, 25, 322-329. https://doi.org/10.1016/j.procs.2013.11.038

Oosterhout, M. V., Waarts, E. \& Hillegersberg, J. V., (2006). Change factors requiring agility and implications for IT. Eur J Inf Syst, 15, 132-145. https://doi.org/10.1057/palgrave.ejis.3000601

Ozdemir, M., Sahin, C., Arcagok, S., \& Demir, M. K. (2018). The effect of augmented reality applications in the learning process: A meta-analysis study. Eurasian Journal of Educational Research, 74, 165-186.

Pallant, J. (2020). SPSS survival manual: A step by step guide to data analysis using IBM SPSS. Routledge. https://doi.org/10.4324/9781003117452

Park, H. M., Lee S. H., \& Choi, J. S. (2008). Wearable augmented reality system using gaze interaction. 7th IEEE/ACM International Symposium on Mixed and Augmented Reality. https://doi.org/10.1109/ISMAR.2008.4637353

Patel, P. (2009). Introduction to Quantitative Methods. [Online] Retrieved from https://hls.harvard.edu/content/uploads/2011/12/quantitative_methods.pdf

Pavan, A. (2016). Higher education in Saudi Arabia: Rooted in heritage and values, aspiring to progress. International Research in Higher Education, 1(1), 91-100. https://doi.org/10.5430/irhe.v1n1p91

Perannagari, K. T., \& Chakrabarti, S. (2019). Factors influencing acceptance of augmented reality in retail: insights from thematic analysis. International Journal of Retail \& Distribution Management. https://doi.org/10.1108/IJRDM-02-2019-0063

Pérez-López, D., \& Contero, M. (2013). Delivering educational multimedia contents through an augmented reality application: A case study on its impact on knowledge acquisition and retention. Turkish Online Journal of Educational Technology-TOJET, 12(4), 19-28.

Ponce, J., Ornelas, F., Álvarez, F., \& Toscano, B. (2018). Use of Augmented Reality a New Vision on the Massive Open Online Courses. In Virtual and Augmented Reality: Concepts, Methodologies, Tools, and Applications (pp. 680-697). IGI Global. https://doi.org/10.4018/978-1-5225-5469-1.ch032

Radu, I. (2012). Why should my students use AR? A comparative review of the educational impacts of augmented-reality. Science and Technology Papers. https://doi.org/10.1109/ISMAR.2012.6402590

Radu, I. (2012, November). Why should my students use AR? A comparative review of the educational impacts of augmented-reality. In 2012 IEEE International Symposium on Mixed and Augmented Reality (ISMAR) (pp. 313-314). IEEE. https://doi.org/10.1109/ISMAR.2012.6402590

Radu, I. (2014). Augmented reality in education: a meta-review and cross-media analysis. Personal and Ubiquitous Computing, 18(6), 1533-1543. https://doi.org/10.1007/s00779-013-0747-y

Rahi, S. (2017). Research design and methods: A systematic review of research paradigms, sampling issues and instruments development. International Journal of Economics \& Management Sciences, 6(2), 1-5. https://doi.org/10.4172/2162-6359.1000403

Rasimah, C. M. Y., Ahmad, A., \& Zaman, H. B. (2011). Evaluation of user acceptance of mixed reality technology. Australasian Journal of Educational Technology, 27(8). https://doi.org/10.14742/ajet.899 
Redondo Domínguez, E., Fonseca Escudero, D., Sánchez Riera, A., \& Navarro Delgado, I. (2017). Educating Urban Designers using Augmented Reality and Mobile Learning Technologies/Formación de Urbanistas usando Realidad Aumentada y Tecnologías de Aprendizaje Móvil. Revista iberoamericana de educación a distancia, 20(2), 141-165. https://doi.org/10.5944/ried.20.2.17675

Rezende, W. J., Albuquerque, E. S., \& Ambrosio, A. P. (2017). Use of Augmented Reality to Support Education-Creating a Mobile E-learning Tool and using it with an Inquiry-based Approach. In CSEDU (1) (pp. 100-107). https://doi.org/10.5220/0006318701000107

Roy, B. (2005). Moving Towards Technology Education: Factors That Facilitated Teachers' Implementation of a Technology Curriculum.Journal of Technology Education, 17(1), 6-18. https://doi.org/10.21061/jte.v17i1.a.1

Ruiz, J. G., Mintzer, M. J., \& Leipzig, R. M. (2006). The impact of E-learning in medical education. Academic medicine, 81(3), 207-212. https://doi.org/10.1097/00001888-200603000-00002

Salinas, P., \& Pulido, R. (2016). Understanding the conics through augmented reality. Eurasia Journal of Mathematics, Science and Technology Education, 13(2), 341-354.

https://doi.org/10.12973/eurasia.2017.00620a

Sarantakos, S. (2013). Social Research. Basingstoke [u.a.]: Palgrave Macmillan. https://doi.org/10.1007/978-1-137-29247-6

Saunders, M., Lewis, P., \& Thornhill, A. (2012). Research Methods for Business Students (6th ed.). Essex, England.

Schmalstieg, D., \& Wagner, D. (2007, November). Experiences with handheld augmented reality. In Mixed and Augmented Reality, 2007. ISMAR 2007. 6th IEEE and ACM International Symposium on (pp. 3-18). IEEE. https://doi.org/10.1109/ISMAR.2007.4538819

Sekaran, U., \& Bougie, R. (2016). Research methods for business: A skill building approach. John Wiley \& Sons.

Singh, D., Mishra, M., \& Sahana, S. (2019). Big-Data-Based Techniques for Predictive Intelligence. In Predictive Intelligence Using Big Data and the Internet of Things (pp. 1-18). IGI Global.

https://doi.org/10.4018/978-1-5225-6210-8.ch001

Stevenson, A. (Ed.). (2010). Oxford dictionary of English. Oxford University Press, USA.

Straub, D., Boudreau, M. C., \& Gefen, D. (2004). Validation guidelines for IS positivist research. Communications of the Association for Information systems, 13(1), 24. https://doi.org/10.17705/1CAIS.01324

Sutherland, I. E. (1968, December). A head-mounted three dimensional display. In Proceedings of the December 9-11, 1968, fall joint computer conference, part I (pp. 757-764). https://doi.org/10.1145/1476589.1476686

Tarng, W., \& Ou, K. L. (2012, March). A study of campus butterfly ecology learning system based on augmented reality and mobile learning. In 2012 IEEE Seventh International Conference on Wireless, Mobile and Ubiquitous Technology in Education (pp. 62-66). IEEE. https://doi.org/10.1109/WMUTE.2012.17

Tavakol, M., \& Dennick, R. (2011). Post-examination analysis of objective tests. Medical Teacher, 33(6), 447-458. https://doi.org/10.3109/0142159X.2011.564682

Tekkesinoglu, S., Sunar, M. S., \& Yusof, C. S. (2013). Towards Building Web Based Augmented Reality Application for Pre-School Children. Indonesian Journal of Electrical Engineering and Computer Science, 11(6), 3134-3141. https://doi.org/10.11591/telkomnika.v11i6.2659

Treiman, D. J. (2014). Quantitative data analysis: Doing social research to test ideas. John Wiley \& Sons.

Urh, M., Vukovic, G., \& Jereb, E. (2015). The model for introduction of gamification into e-learning in higher education. Procedia-Social and Behavioral Sciences, 197, 388-397. https://doi.org/10.1016/j.sbspro.2015.07.154

Van Krevelen, D. W. F., \& Poelman, R. (2010). A survey of augmented reality technologies, applications and limitations. International journal of virtual reality, 9(2), 1. https://doi.org/10.20870/IJVR.2010.9.2.2767

Volonté, F., Buchs, N. C., Pugin, F., Spaltenstein, J., Schiltz, B., Jung, M., ... \& Morel, P. (2013). Augmented reality to the rescue of the minimally invasive surgeon. The usefulness of the interposition of stereoscopic images in the Da Vinci ${ }^{\mathrm{TM}}$ robotic console. The International Journal of Medical Robotics and Computer Assisted Surgery, 9(3), e34-e38. https://doi.org/10.1002/rcs.1471 
Wang, M., Shen, R., Tong, R., Yang, F., \& Han, P. (2005, July). Mobile learning with cellphones and PocketPCs. In International Conference on Web-Based Learning (pp. 332-339). Springer, Berlin, Heidelberg. https://doi.org/10.1007/11528043_34

Wiedersheim-Paul, F., \& Eriksson, L. T. (1991). Att utreda, forska och rapportera. Liber ekonomi/Almqvist \& Wiksell.

Williams, C. (2007). Research methods. Journal of business \& economic research, 5(3), 65-72. https://doi.org/10.19030/jber.v5i3.2532

Wojciechowski, R., \& Cellary, W. (2013). Evaluation of learners' attitude toward learning in ARIES augmented reality environments. Computers \& Education, 68, 570-585. https://doi.org/10.1016/j.compedu.2013.02.014

Wu, H. K., Lee, S. W. Y., Chang, H. Y., \& Liang, J. C. (2013). Current status, opportunities and challenges of augmented reality in education. Computers \& education, 62, 41-49. https://doi.org/10.1016/j.compedu.2012.10.024

Wu, P. H., Hwang, G. J., Yang, M. L., \& Chen, C. H. (2018). Impacts of integrating the repertory grid into an augmented reality-based learning design on students' learning achievements, cognitive load and degree of satisfaction. Interactive Learning Environments, 26(2), 221-234. https://doi.org/10.1080/10494820.2017.1294608

Y1lmaz, R. M. (2014). Effects of Three-Dimensional Storytelling Developed with Augmented Reality Technology on Narrative Skill and Creativity. Unpublished Doctoral Dissertation), Atatürk Üniversitesi, Erzurum.

Yilmaz, R. M. (2018). Augmented Reality Trends in Education between 2016 and 2017 Years. State of the Art Virtual Reality and Augmented Reality Knowhow. https://doi.org/10.5772/intechopen.74943

Yuen, S. C. Y., Yaoyuneyong, G., \& Johnson, E. (2011). Augmented reality: An overview and five directions for AR in education. Journal of Educational Technology Development and Exchange (JETDE), 4(1), 11. https://doi.org/10.18785/jetde.0401.10

Yuen, S. C. Y., Yaoyuneyong, G., \& Johnson, E. (2013). Augmented reality and education: Applications and potentials. In Reshaping Learning (pp. 385-414). Springer, Berlin, Heidelberg. https://doi.org/10.1007/978-3-642-32301-0_17

Zhou, F., Duh, H. B., \& Billinghurst, M. (2008). Trends in augmented reality tracking, interaction and display: A review of ten years of ISMAR. 7th IEEE/ACM International Symposium on Mixed and Augmented Reality.

Zhu, E., Hadadgar, A., Masiello, I., \& Zary, N. (2014). Augmented reality in healthcare education: an integrative review. PeerJ, 2. https://doi.org/10.7717/peerj.469

\section{Copyrights}

Copyright for this article is retained by the author(s), with first publication rights granted to the journal.

This is an open-access article distributed under the terms and conditions of the Creative Commons Attribution license (http://creativecommons.org/licenses/by/4.0/). 